\title{
Global distribution of the effective aerosol hygroscopicity parameter for $\mathrm{CCN}$ activation
}

\author{
K. J. Pringle ${ }^{1}$, H. Tost ${ }^{1}$, A. Pozzer ${ }^{1,2}$, U. Pöschl ${ }^{1}$, and J. Lelieveld ${ }^{1,2}$ \\ ${ }^{1}$ Max Planck Institute for Chemistry, Mainz, Germany \\ ${ }^{2}$ The Cyprus Institute, Energy, Environment and Water Research Centre, Nicosia, Cyprus
}

Received: 29 January 2010 - Published in Atmos. Chem. Phys. Discuss.: 8 March 2010

Revised: 1 June 2010 - Accepted: 9 June 2010 - Published: 15 June 2010

\begin{abstract}
In this study we use the ECHAM/MESSy Atmospheric Chemistry (EMAC) model to simulate global fields of the effective hygroscopicity parameter $\kappa$ which approximately describes the influence of chemical composition on the cloud condensation nucleus (CCN) activity of aerosol particles. The obtained global mean values of $\kappa$ at the Earth's surface are $0.27 \pm 0.21$ for continental and $0.72 \pm 0.24$ for marine regions (arithmetic mean \pm standard deviation). These values are the internally mixed $\kappa$ calculated across the Aitken and accumulation modes. The mean $\kappa$ values are in good agreement with previous estimates based on observational data, but the model standard deviation for continental regions is higher.
\end{abstract}

Over the continents, the regional distribution appears fairly uniform, with $\kappa$ values mostly in the range of $0.1-0.4$. Lower values over large arid regions and regions of high organic loading lead to reduced continental average values for Africa and South America (0.15-0.17) compared to the other continents $(0.21-0.36)$. Marine regions show greater variability with $\kappa$ values ranging from $0.9-1.0$ in remote regions to $0.4-0.6$ in continental outflow regions where the highly hygroscopic sea spray aerosol mixes with less hygroscopic continental aerosol. Marine $\kappa$ values as low as $0.2-0.3$ are simulated in the outflow from the Sahara desert.

At the top of the planetary boundary layer the $\kappa$ values can deviate substantially from those at the surface (up to 30\%) - especially in marine and coastal regions. In moving from the surface to the height of the planetary boundary layer, the global average marine $\kappa$ value reduces by $20 \%$. Thus, surface observations may not always be representative for the altitudes where cloud formation mostly occurs.

In a pre-industrial model scenario, the $\kappa$ values tend to be higher over marine regions and lower over the continents,

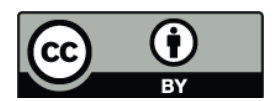

Correspondence to: K. J. Pringle (kirsty.pringle@mpic.de) because the anthropogenic particulate matter is on average less hygroscopic than sea-spray but more hygroscopic than the natural continental background aerosol (dust and organic matter). In regions influenced by desert dust the particle hygroscopicity has increased strongly as the mixing of air pollutants with mineral particles typically enhances the $\kappa$ values by a factor of 2-3 above the initial value of $\approx 0.005$.

\section{Introduction}

The ability of aerosol particles to take up water vapour influences both their direct and indirect effects on climate. The aerosol water content controls the aerosol ambient radius which in turn controls the ability of the particle to interact with solar radiation (direct effect). Also, it is the largest and most hydrophilic particles that are able to act as cloud condensation nuclei $(\mathrm{CCN})$ and form cloud droplets (indirect aerosol effects).

The effective hygroscopicity parameter $\kappa$ offers a simple way of describing the influence of chemical composition on the CCN activity of aerosol particles (Petters and Kreidenweis, 2007). It can be used to calculate the $\mathrm{CCN}$ concentration, i.e., the number of particles within an aerosol population that will activate at a specified water vapour supersaturation in Köhler model calculations without explicitly resolving the density, molecular mass and van't Hoff factor or osmotic coefficient and dissociation number of each chemical component. The applicability and usefulness of $\kappa$ has been demonstrated in numerous recent studies, including model simulations (e.g. Kim et al., 2008; Spracklen et al., 2008; Ruehl et al., 2009; Reutter et al., 2009), field measurements (e.g. Snider and Petters, 2008; Wang et al., 2008; Gunthe et al., 2009; Bougiatioti et al., 2009; Dusek et al., 2010; Rose et al., 2010; Shinozuka et al., 2010) and laboratory experiments (e.g. Rose et al., 2008; Niedermeier et al., 2008; Mikhailov et al., 2009; Wex et al., 2009). 
Based on a review of observational data, Andreae and Rosenfeld (2008) suggested that continental and marine aerosols on average tend to cluster into relatively narrow ranges of effective hygroscopicity (continental $\kappa=0.3 \pm 0.1$; marine $\kappa=0.7 \pm 0.2$ ). Recent field studies are largely consistent with this view, but they show also systematic deviations for certain regions and conditions. For example, Gunthe et al. (2009) reported a characteristic value of $\kappa=0.15$ for pristine tropical rainforest aerosols in central Amazonia, which are largely composed on secondary organic matter.

Currently, the availability of observational data is not sufficient to obtain a clear picture of the global distribution and characteristic regional differences of $\kappa$. In this study we use a general circulation model to calculate the global distribution of $\kappa$. We outline and discuss horizontal and vertical distribution patterns on regional and global scales, and we compare the model results with field measurement data. Moreover, we present the results of a pre-industrial model scenario and discuss the effects of anthropogenic emissions. To our knowledge, such information has not been published before, and we hope that it will be useful for further experimental and theoretical studies of the hygroscopic properties and climate effects of atmospheric aerosols.

\section{Methods}

\subsection{Model description}

We used the ECHAM-MESSy Atmospheric Chemistry model (EMAC) to simulate global fields of aerosol loading and properties, including the hygroscopicity parameter $\kappa$ as detailed below. EMAC is a combination of the ECHAM5 general circulation model (Roeckner et al., 2006) and the Modular Earth Submodel System (Jöckel et al., 2005, 2006). For a full description of the EMAC model and evaluation see Jöckel et al. $(2005,2006)$ or http://www.messy-interface.org. The model was run for a year with a spectral resolution of T42 degrees and with 19 levels in the vertical. The model was weakly nudged towards real meteorology using ECWMF analysis data for the year 2002.

Gas-phase chemistry is calculated in EMAC using the MECCA submodel (Sander et al., 2005). The wet deposition of gases and aerosols (both nucleation and impaction scavenging) is treated within the SCAV submodel (Tost et al., 2006, 2007a), which describes scavenging due to convective and large-scale rain, snow and ice. Dry deposition is treated using the big leaf approach within the DRYDEP submodel (Ganzeveld and Lelieveld, 1995; Kerkweg et al., 2006a). Sedimentation is treated within the SEDI submodel (Kerkweg et al., 2006a). Emission of gas and aerosols is treated by the ONLEM and OFFLEM routines (Kerkweg et al., 2006a). The other submodels used in this study are CONVECT (Tost et al., 2006), LNOX (Tost et al., 2007b), TNUDGE (Kerk- weg et al., 2006b), as well as CLOUD, CVTRANS, JVAL, RAD4ALL, and TROPOP (Jöckel et al., 2006).

The aerosol distribution is simulated using the GMXe model which simulates the distribution of sulfate, black carbon, organic carbon, nitrate, ammonium, dust and sea salt aerosol using 4 hydrophilic and 3 hydrophobic log-normal modes (in a similar approach to that of Vignati et al., 2004; Stier et al., 2005) in the following size ranges: nucleation ( $<5 \mathrm{~nm}$ radius), Aitken $(5-50 \mathrm{~nm})$, accumulation (50$500 \mathrm{~nm})$ and coarse $(>500 \mathrm{~nm})$. The 4 hydrophilic modes comprise a nucleation, Aitken, accumulation and coarse modes, the 3 hydrophobic modes are Aitken, accumulation and coarse modes. The aerosol composition within each mode is internally mixed, but the 7 modes are externally mixed with respect to each other, and notably the hydrophobic and hydrophillic modes are chemically distinct.

Emission of black carbon (BC), organic carbon (OC), dust and sea salt aerosol are all taken from the AeroCom inventory (Dentener et al., 2006). To account for the presence of organic material and sulfate in the emitted sea spray aerosol, we assumed that $10 \%$ of accumulation mode sea spray consists of organic material and that $4 \%$ of the accumulation and coarse mode fluxes are marine sulfate (the rest was assumed to be $\mathrm{NaCl}$ ). This approach is a simple approximation, but it is sufficient to avoid an overestimation of water uptake by sea spray aerosol. It resulted in a $\kappa$ value of approximately 1.0 for freshly emitted sea spray aerosol, which is in good agreement with the experimental results of Niedermeier et al. (2008). More sophisticated treatments will be considered in future work.

The aerosol fields are compared to observations in Pringle et al. (2010), but to summarise, the model simulates global fields of the bulk aerosol species (SO4, DU, BC, OC and sea salt (SS)) within the range of the AeroCom global models and with comparable proficiency to the ECHAM-HAM model (Stier et al., 2005). Nitrate ion concentrations have been compared to observations from EMEP (Europe) and CASTNET (N. America); annual mean modelled values compare to observations with a geometric mean ratio of 0.95 (EMEP) and 1.43 (CASTNET) with 77\% (EMEP) and 50\% (CASTNET) of modelled nitrate values within a factor of two of the observations. In the EMAC version applied in this study, $\kappa$ was calculated as a diagnostic parameter that does not feedback on any other simulated parameter.

\subsection{Calculation of $\kappa$}

The effective aerosol hygroscopicity parameter $\kappa$ is was calculated according to the simple mixing rule proposed by Petters and Kreidenweis (2007);

$\kappa_{n}=\sum_{i} \epsilon_{i, n} \kappa_{i}$

where $\epsilon_{i, n}$ and $\kappa_{i}$ are the volume fraction and hygroscopicity parameter of the chemical component $i$ in mode 
$n$. The following parameter values were taken from Petters and Kreidenweis (2007) (“CCN derived $\kappa$ ”): 0.61 for $\left(\mathrm{NH}_{4}\right)_{2} \mathrm{SO}_{4}, 0.67$ for $\mathrm{NH}_{4} \mathrm{NO}_{3}, 1.28$ for $\mathrm{NaCl}, 0.90$ for $\mathrm{H}_{2} \mathrm{SO}_{4}, 0.88$ for $\mathrm{NaNO}_{3}, 0.91$ for $\mathrm{NaHSO}_{4}, 0.80$ for $\mathrm{Na}_{2} \mathrm{SO}_{4}, 0.65$ for $\left(\mathrm{NH}_{4}\right)_{3} \mathrm{H}\left(\mathrm{SO}_{4}\right)_{2}$ For black carbon and dust we took $\kappa_{i}=0$, and for organic carbon we took $\kappa_{i}=0.1$ (Wang et al., 2008; Gunthe et al., 2009; Pöschl et al., 2009; Dusek et al., 2010; King et al., 2010). The assumed density $\left(\mathrm{g} \mathrm{cm}^{-3}\right)$ of each species is 1.70 for $\left(\mathrm{NH}_{4}\right)_{2} \mathrm{SO}_{4}$, 1.72 for $\mathrm{NH}_{4} \mathrm{NO}_{3}, 2.17$ for $\mathrm{NaCl}, 1.84$ for $\mathrm{H}_{2} \mathrm{SO}_{4}, 2.26$ for $\mathrm{NaNO}_{3}, 1.48$ for $\mathrm{NaHSO}_{4}, 2.66$ for $\mathrm{Na}_{2} \mathrm{SO}_{4}, 1.78$ for $\left(\mathrm{NH}_{4}\right)_{3} \mathrm{H}\left(\mathrm{SO}_{4}\right)_{2}, 2.0$ for black and organic carbon and 2.65 for dust.

According to Eq. (1), we calculated $\kappa$ for each of the seven aerosol modes of the model. For presentation and discussion we then calculate, from these mode dependent $\kappa$ values, the volume weighted mean value of the Aitken and accumulation modes as this size range is most relevant for atmospheric $\mathrm{CCN}$ concentrations in the atmosphere and thus for comparison to field observations. For the $\kappa$ values presented in this work, we consider the volume fraction of each component in both the hydrophilic and hydrophobic modes, which corresponds to the bulk composition of fine particulate matter:

$\kappa=\sum \kappa_{n} \cdot\left(V_{n} / V_{t}\right)$

where $\kappa_{n}$ is the calculated $\kappa$ of mode $n$ and $V_{n}$ is the volume of mode $n$ and $V_{t}$ is the aerosol volume summed across the relevant modes (Aitken hydrophilic, accumulation hydrophilic, Aitken hydrophobic and accumulation hydrophobic).

As demonstrated in several recent studies, this approach is well suited for approximate calculations of CCN number concentrations from size distributions and bulk chemical composition data of atmospheric aerosols (e.g., Wang, 2008; Bugiatioti, 2009; Chang, 2009; Gunthe, 2009; Shinozuka, 2009; Shantz, 2009; Ervens, 2009). However, by calculating a mean $\kappa$ averaged between the hydrophobic and hydrophilic modes we loose information on the mixing state of the aerosol, which may lead to biases if these fields were to be used directly to calculate global fields of $\mathrm{CCN}$ in regions where there is a high degree of external mixing (e.g. some urban regions, see Cubison et al., 2008). The $\kappa$ values presented are comparable to measurement-derived $\kappa$ values describing the total ensemble of $\mathrm{CCN}$-active and -inactive aerosol particles $\left(\kappa_{t}\right.$ as presented and discussed by Gunthe et al. (2009) and Rose et al. (2010)).

In the supplement we present an alternative data set considering only the hydrophilic Aitken and accumulation modes. The $\kappa$ values calculated this way are comparable to measurement-derived $\kappa$ values describing only the $\mathrm{CCN}$ active particle fraction ( $\kappa_{a}$ as presented and discussed by Rose et al. (2010) and Gunthe et al. (2009)). Depending on the proportion of hydrophobic and $\mathrm{CCN}$-inactive particles, these $\kappa$ values can be significantly higher: the global conti- nental average $\kappa_{a}$ value is 0.07 (25\%) larger than that calculated considering both hydrophilic and hydrophobic modes, but this offset is fairly constant between regions (range of 0.07 to 0.10 ). Marine $\kappa$ values are less sensitive as there are fewer hydrophobic particles and thus $\kappa_{a}$ is just $0.04(5 \%)$ larger.

For Köhler model calculations linking $\kappa$ to particle size and critical supersaturation for $\mathrm{CCN}$ activation, we used the surface tension of pure water $\left(0.072 \mathrm{~J} \mathrm{~m}^{-2}\right)$. This corresponds to the assumption that the effective hygroscopicity parameter accounts for solute effects on both water activity and surface tension (Petters and Kreidenweis, 2007; Gunthe et al., 2009; Pöschl et al., 2009; Rose et al., 2010).

Throughout this text we present the calculated standard deviation of the simulated $\kappa$ values. Unless otherwise stated these standard deviations are calculated from data with a temporal resolution of five hours.

\section{Results and discussion}

\subsection{Comparison with observations}

The average effective hygroscopicity parameters calculated for continental and marine regions are $\kappa_{\text {continental }}=0.27 \pm 0.21$ and $\kappa_{\text {marine }}=0.72 \pm 0.24$, respectively (surface level, Table 1). The mean value and standard deviation of $\kappa_{\text {marine }}$ are practically identical to the observation-based estimate of Andreae and Rosenfeld (2008). For $\kappa_{\text {continental }}$ the model-calculated mean value is about $10 \%$ lower and the standard deviation is a factor of two higher than the estimate of Andreae and Rosenfeld (2008). Note, however, that the standard deviations calculated and reported in this study include both spatial and temporal variability unless noted otherwise (see Sect. 3.5.), whereas the observations reviewed by Andreae and Rosenfeld (2008) were mostly short-term measurements providing only limited information about temporal variability. Considering that the two approaches used to estimate the average continental and marine $\kappa$ values (Andreae and Rosenfeld, 2008, and ours) are completely different and independent, we find the overall agreement between the two studies quite good. In view of the limited observational database, we suggest that the model-derived standard deviation may be a more realistic estimator for the variability of $\kappa$ in continental aerosols.

A recent study by Wex et al. (2010) re-analysed data from AMS and HTDMA measurements taken in a range of locations and presented typical $\kappa$ values for different conditions, making the distinction between a more hygroscopic and less hygroscopic modes that can be distinguished by the HTDMA. They found $\kappa$ values of $0.3,0.24$ and 0.45 for urban, rural and marine aerosols in the more hygroscopic modes and $0.02,0.04$ and 0.08 in the less hygroscopic mode. Urban and rural values agree well with the model simulated mean continental value, but the Wex et al. (2010) data suggests a lower 
Table 1. Simulated global and regional annual mean $\kappa$ values (and standard deviation (St Dev)) at the surface and at the simulated PBL height under present day conditions. Standard deviation is calculated for the year from 5-hourly average data. $S_{C}$ is the critical supersaturation, calculated using the regional mean $\kappa$ at PBL height. Area column gives total land area for land sites, and marine area for marine sites.

\begin{tabular}{lccccccc}
\hline Region & $\begin{array}{c}\text { Area } \\
\left(10^{13} \mathrm{~m}^{2}\right)\end{array}$ & $\begin{array}{c}\text { Mean } \kappa \\
\text { Surface }\end{array}$ & $\begin{array}{c}\text { St Dev } \\
\text { Surface }\end{array}$ & $\begin{array}{c}\text { Mean } \kappa \\
\text { PBL height }\end{array}$ & $\begin{array}{c}\text { St Dev } \\
\text { PBL height }\end{array}$ & $\begin{array}{c}S_{c}(\%) \\
D_{p}=60(\mathrm{~nm})\end{array}$ & $\begin{array}{c}S_{c}(\%) \\
D_{p}=120(\mathrm{~nm})\end{array}$ \\
\hline Global (Continental) & 14.4 & 0.27 & 0.21 & 0.27 & 0.20 & 0.48 & 0.17 \\
Global (Marine) & 37.0 & 0.72 & 0.24 & 0.60 & 0.25 & 0.33 & 0.11 \\
\hline N. America & 1.61 & 0.30 & 0.15 & 0.29 & 0.14 & 0.47 & 0.17 \\
S. America & 1.90 & 0.17 & 0.14 & 0.18 & 0.13 & 0.59 & 0.21 \\
Africa & 3.48 & 0.15 & 0.12 & 0.17 & 0.11 & 0.61 & 0.22 \\
Europe & 1.14 & 0.36 & 0.16 & 0.33 & 0.15 & 0.44 & 0.15 \\
Asia & 3.64 & 0.22 & 0.15 & 0.22 & 0.13 & 0.54 & 0.19 \\
Australia & 0.87 & 0.21 & 0.16 & 0.23 & 0.15 & 0.52 & 0.19 \\
\hline N. Atlantic & 1.25 & 0.59 & 0.18 & 0.47 & 0.18 & 0.37 & 0.13 \\
Southern Ocean & 1.56 & 0.92 & 0.09 & 0.80 & 0.17 & 0.28 & 0.10 \\
\hline
\end{tabular}

Table 2. Comparison between observed and modelled $\kappa$ values. ${ }^{A} \kappa$ calculated from reported aerosol soluble fraction, following Gunthe et al. (2009). Most measurement sites were surface campaigns, with the exception of Shinozuka et al. (2010) and Hudson (2007), which are flight data. For flight data an average altitude of approx. $1500(\mathrm{~m})$ was assumed.

\begin{tabular}{lllcc}
\hline Site & Region & Reference & $\kappa$ observed & $\kappa$ model \\
\hline 1 & Amazon & Gunthe et al. (2009) & $0.16 \pm 0.06$ & 0.11 \\
2 & China & Rose et al. (2010) & 0.3 & 0.37 \\
3 & Mexico & Shinozuka et al. (2010) & $0.2-0.3$ & 0.35 \\
4 & US West Coast & Shinozuka et al. (2010) & $0.18-0.47$ & 0.23 \\
5 & Puerto Rico & Allan et al. (2008) & $0.6 \pm 0.2$ & 0.70 \\
6 & Antigua & Hudson (2007) & $0.87 \pm 0.24$ & 0.72 \\
7 & Amazon & Vestin et al. (2007) & 0.10 & 0.08 \\
8 & Amazon & Zhou et al. (2002) & 0.12 & 0.11 \\
9 & Tenerife & Guibert et al. (2003) & 0.43 & 0.58 \\
10 & Germany (Feldberg) & Dusek et al. (2006) & $0.15-0.3$ & 0.32 \\
11 & Germany (Munich) & Kandler and Shütz (2007) & 0.36 & 0.27 \\
12 & Eastern Mediterranean & Bougiatioti et al. (2009) & 0.24 & 0.44 \\
13 & Toronto & Broekhuizen et al. (2006) & $0.15-0.3$ & 0.31 \\
14 & Ontario & Chang et al. (2010) & 0.3 & 0.26 \\
\hline
\end{tabular}

marine $\kappa$ than that simulated by EMAC and that suggested by Andreae and Rosenfeld (2008). This is partly due to the fact that our marine value also includes data from the Southern Ocean where $\kappa$ values are large $(>0.9$, Fig. 1$)$ whereas the marine data analysed by Wex et al. (2010) is often in continental outflow regions where values of 0.5 to 0.7 are more common. Furthermore, it is conceivable that we underestimate the effects of the organic fraction in sea salt particles, which acts to reduce $\kappa$.

In Table 2 we compare effective hygroscopicity parameters derived from $\mathrm{CCN}$ measurements at various locations around the world to the values of $\kappa$ calculated by EMAC for the these regions (monthly mean modelled values for the time period of each campaign are used). Due to the large size of the global model grid boxes (approx. $250 \mathrm{~km}$ ), the compari- son with point observations is uncertain but necessary as no large-scale (e.g. satellite) measurements of $\kappa$ exist. Note also that the model values are representative for the year 2002, whereas the observations were gathered over a range of different years.

Nevertheless, the model results are in fair agreement with most observations. The deviations between modelled and observed $\kappa$ values were $\leq 0.05$ for 10 out of the 14 measurement locations.

For Tenerife and the Eastern Mediterranean site the model over-predicts $\kappa$ (bias $\geq 0.15)$. This overestimation could be due to the fact that the model tends to overestimate the transport of sea salt into coastal continental regions (also found by Kerkweg et al., 2008) as the strong coastal gradients are underestimated in the large grid boxes. 


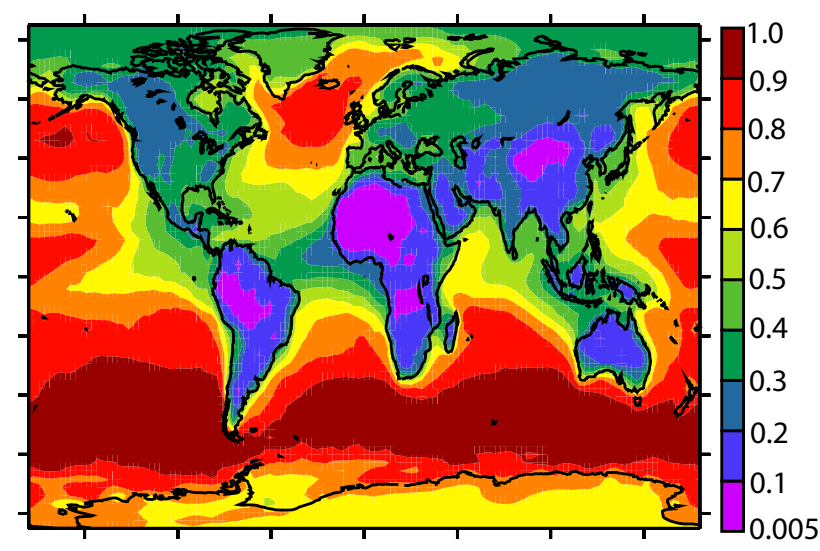

Fig. 1. Annual mean distribution of $\kappa$ at the surface simulated by EMAC.

Overall, we find the agreement between model results and observations quite satisfactory when considering the uncertainties and complications involved in the comparison of a global model with sparse field measurement data.

\subsection{Global distribution}

Figure 1 shows the simulated annual mean global distribution of $\kappa$. This figure allows us to put the observed $\kappa$ values (discussed above) in the context of a wider geographical pattern.

The first thing to note is that in line with observations, the model simulates a distribution of $\kappa$ that has a strong land/sea contrast: the majority of continental $\kappa$ values lie in the range of 0.1 to 0.4 , but marine regions have larger $\kappa$ values, with most values $>0.6$. Inland continental regions strongly influenced by dust have the lowest simulated $\kappa$, with values $<0.1$. No regions have an annual mean $\kappa$ of below 0.005 .

The low resolution of the global model (T42) will underestimate the horizontal variability of $\kappa$, with values averaged over large gridboxes (approx. $250 \mathrm{~km}$ ), but even if this effect is considered, the rate of change of $\kappa$ across a geographic region is quite low, with regions of thousands of square kilometres showing quite constant annual mean values.

Coastal regions show the strongest horizontal gradient in $\kappa$ and thus it is in these regions that the air mass history may significantly affect the water uptake potential of the aerosol and must therefore be considered in calculations.

One of the most striking aspects of Fig. 1 is the clear influence of the continental regions on the marine $\kappa$ values. Marine regions downwind of continental outflow regions have a reduced $\kappa$ value, with some values as low as 0.2 (due to dust outflow from N. Africa). Outflow of anthropogenic pollution also influences $\kappa$; for example in the Gulf of Mexico the $\kappa$ value is 0.4 , clearly reduced from the "unpolluted" marine $\kappa$ values of $>0.8$. This effect extends over large parts of the

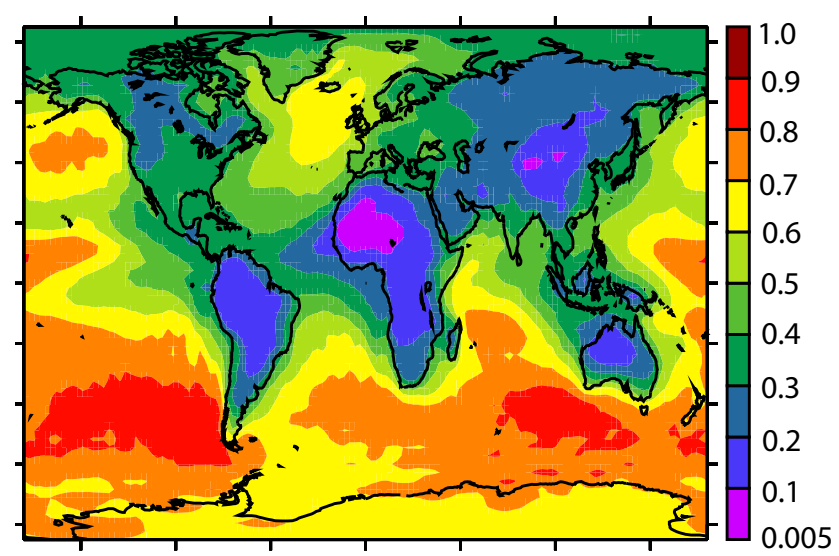

Fig. 2. Annual mean distribution of $\kappa$ at the altitude of the planetary boundary layer.

ocean where the continental influence is large and is particularly important where wind speeds are relatively low (and thus sea spray concentrations are quite small).

As the water uptake ability of the aerosol is important for cloud droplet formation, which occurs above the surface layer, it is also interesting to consider the distribution of $\kappa$ at higher altitudes. Figure 2 shows $\kappa$ at the simulated planetary boundary layer (PBL) height. We choose to extract $\kappa$ at the modelled PBL height, as it is a region of active cloud formation and therefore an altitude relevant for consideration of $\mathrm{CCN}$ and activation. In EMAC, the PBL height is calculated using the TROPOP submodel (following the method of Holtslag et al., 1990; Holtslag and Boville, 1993) and can vary from 23 to $7291 \mathrm{~m}$ (the latter in mountainous regions), with an average value of $482 \mathrm{~m}$ above sea level.

At PBL height (as at the surface) there is a clear land/sea contrast, with low values $(0.1-0.3)$ in S. America, parts of Africa and central Asia. Marine values are significantly lower above the surface layer; values $>0.9$ do not occur and the global mean marine $\kappa$ value is reduced to 0.60 (from 0.72 ), reflecting the more aged nature of the aerosol distribution and the reduced influence of sea salt. At the PBL height, the simulated annual mean $\kappa$ value is uniform over quite large geographical areas, although some coastal regions still show a strong horizontal gradient.

\subsection{Vertical profiles}

The vertical distribution of aerosol is controlled by both large scale meteorological features and chemical processing of aerosol (Morgan et al., 2009), the result of which is that the aerosol composition at the surface can be quite different from that aloft. To further elucidate the change in $\kappa$ with altitude Fig. 3 shows vertical profiles of $\kappa$ at the measurement sites shown in Fig. 4. As most of these measurement sites are continental, additional profiles from a selection of 

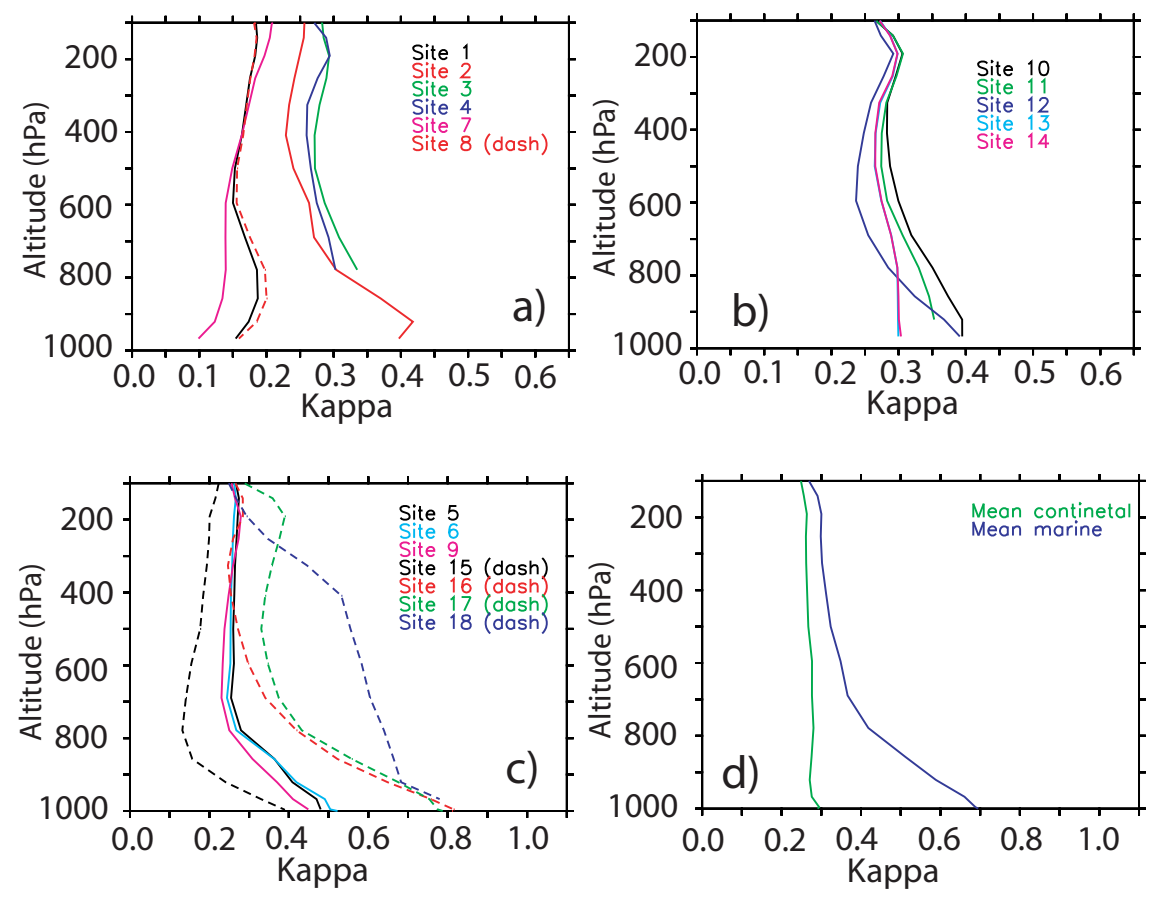

Fig. 3. Vertical distribution of $\kappa$ at the sites shown in Fig. 4. Plots (a) and (b) show continental sites plot (c) shows continental sites with strong marine influence (solid line) and marine sites (dash) and plot (d) shows the vertical profile of the global mean of all continental and all marine regions. Note $\mathrm{x}$-axis changes between plots.

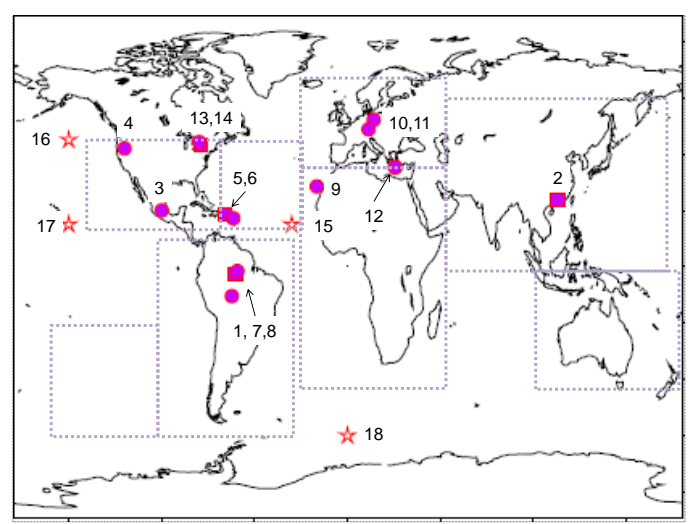

Fig. 4. Summary of the regions used in the consideration of regional values (large dashed boxes) and the approximate location of the field observation sites (over-plotted circles and squares). Stars represent additional regions taken for vertical profile plots.

marine regions are also shown. In this way we can see how representative surface $\kappa$ values are for higher altitudes.
The variation of $\kappa$ with altitude of the single sites is complex. Amazonian sites $(1,7,8)$ show an increase in $\kappa$ with altitude caused by the hydrophobic BC particles ageing and become more hydrophilic at higher altitudes (up to $800 \mathrm{hPa}$, after which $\kappa$ decreases). The continentally influenced marine sites $(5,6,15,16$, and 17) all show a decrease in $\kappa$ with altitude up to approximately $800 \mathrm{hPa}$ (at which altitude $\kappa$ can be $>30 \%$ smaller than at the surface). Although the S. Ocean site (18) shows an initial decline in $\kappa$ the rate of decrease in $\kappa$ with altitude is lower than the other marine sites as the influence of other (non-sea salt) aerosol types is smaller in this region. The marine sites show quite varied $\kappa$ values even at high altitude. For example, the $\kappa$ of Site 15 , which is in the Saharan outflow region is still significantly below that of marine $\kappa$ values in less dusty regions. Although this is an extreme case (as few marine regions are so strongly influenced by continental aerosol) it is worth noting as at approximately $800 \mathrm{hPa}$ the $\kappa$ of Site 15 is $<0.2$, which is far from the "typical" marine value.

The Canadian sites (13 and 14) have a $\kappa$ profile that is almost constant with height (up to $800 \mathrm{hPa}$ ) but the German sites (10 and 11) have a higher $\kappa$ at surface and decrease with altitude, so that at $600 \mathrm{hPa}$ the $\kappa$ of the two regions is similar. At Site 12 (Mediterranean) $\kappa$ decreases quite strongly with height. At the altitude of $100 \mathrm{hPa}$, all sites have a $\kappa$ of between 0.15 and 0.4 . 

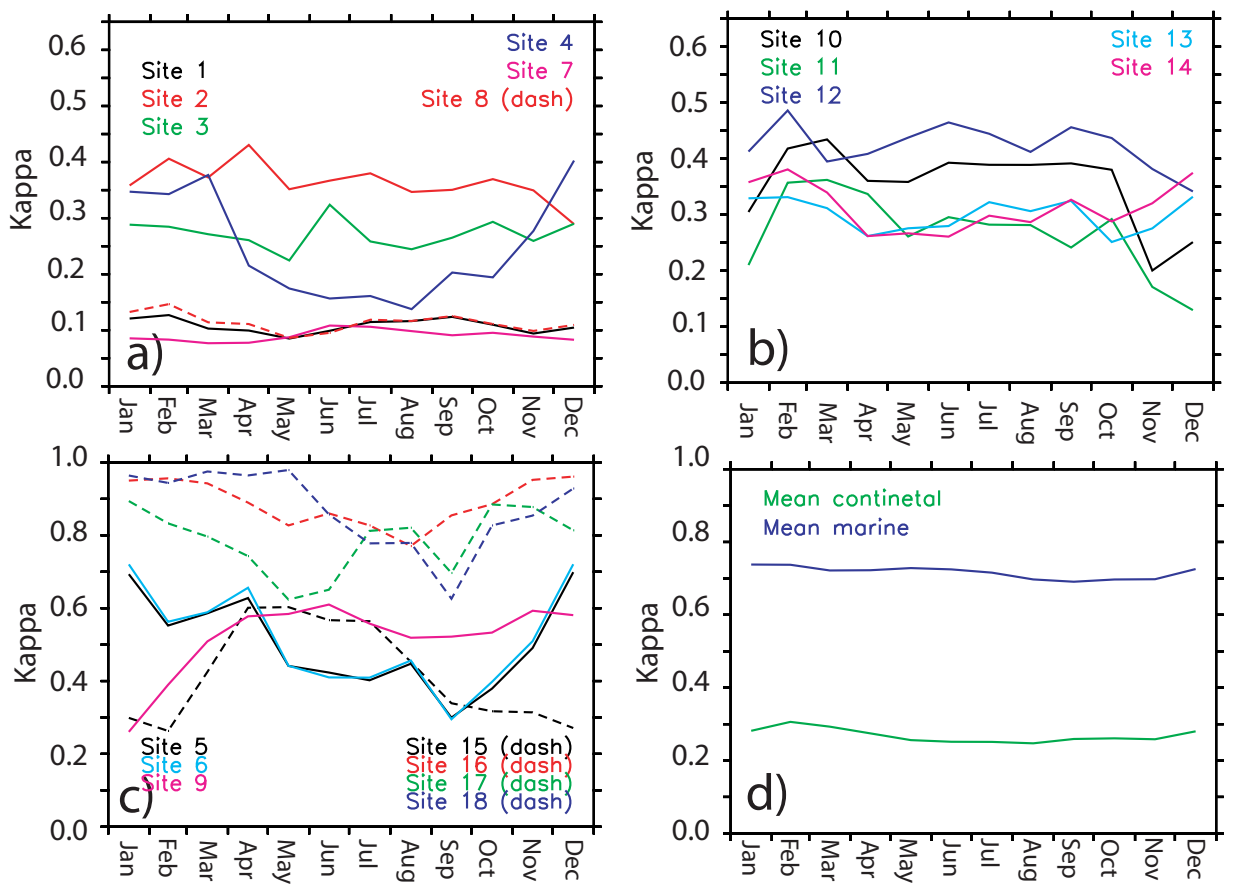

Fig. 5. Annual cycle of monthly mean $\kappa$ at the surface at sites shown in Fig. 4. Plots (a) and (b) show continental sites plot (c) shows continental sites with strong marine influence (solid line) and marine sites (dash) and plot (d) shows the annual cycle of the global mean of all continental and all marine regions. Note y-axis changes between plots.

Panel $\mathrm{d}$ shows the vertical variation of $\kappa$ averaged over all continental and all marine sites. The different vertical profiles of the continental sites tend to counteract each other, leading to a distribution that is almost constant with height. The mean marine profile, however, shows a strong decrease with height, with values reducing from 0.7 at the surface to 0.4 at $700 \mathrm{hPa}$.

\subsection{Annual cycle}

Many aerosol sources have a seasonal cycle and, often as a result of this, the chemical composition of the aerosol can change throughout the year, which can potentially affect $\kappa$. As most $\kappa$ measurements are taken from field campaigns lasting a few weeks, it is worth examining how $\kappa$ changes throughout the year to see how representative short term measurements are. Figure 5 shows the seasonal cycle of $\kappa$ at each of the measurement sites considered previously (see Fig. 4).

The seasonal cycle of $\kappa$ is complex: all sites show some variation with month, although there is little consistency in the shape of the cycle. In Puerto Rico and Antigua (5 and $6), \kappa$ is $>0.5$ in the northern hemisphere winter and reaches a minimum of 0.3 in September. The mid Atlantic site (15) has $\kappa$ at a maximum in April and a minimum in winter.
Overall, at particular sites, the seasonal variation in $\kappa$ can be strong, but the cycle varies so significantly between sites that it is difficult to draw a general trend. In many sites $\kappa$ varies by $\pm 20 \%$ through the season, thus care must be taken when extrapolating from short term measurements to annual mean values. The global mean continental and marine $\kappa$ shows almost no seasonal cycle because the different cycles of the different locations cancel each other out.

\subsection{Regional distributions}

\subsubsection{Continental}

To examine the variability of $\kappa$ within a region in more detail Fig. 6 shows histograms of the frequency of occurrence of particular $\kappa$ values in 6 different continental regions: N. America, S. America, Africa, Europe, Asia and Australia (See Fig. 4) at both the surface (black line) and at PBL height (red line). The values taken for this analysis are annual mean values. In addition, Table 1 shows the average annual mean $\kappa$ for each region.

The frequency distribution of $\kappa$ on a continental scale is dependent on the region considered: S. America has very low $\kappa$ values, particularly at the surface, where 0.1 is the most common value. The distribution also shows relatively little 

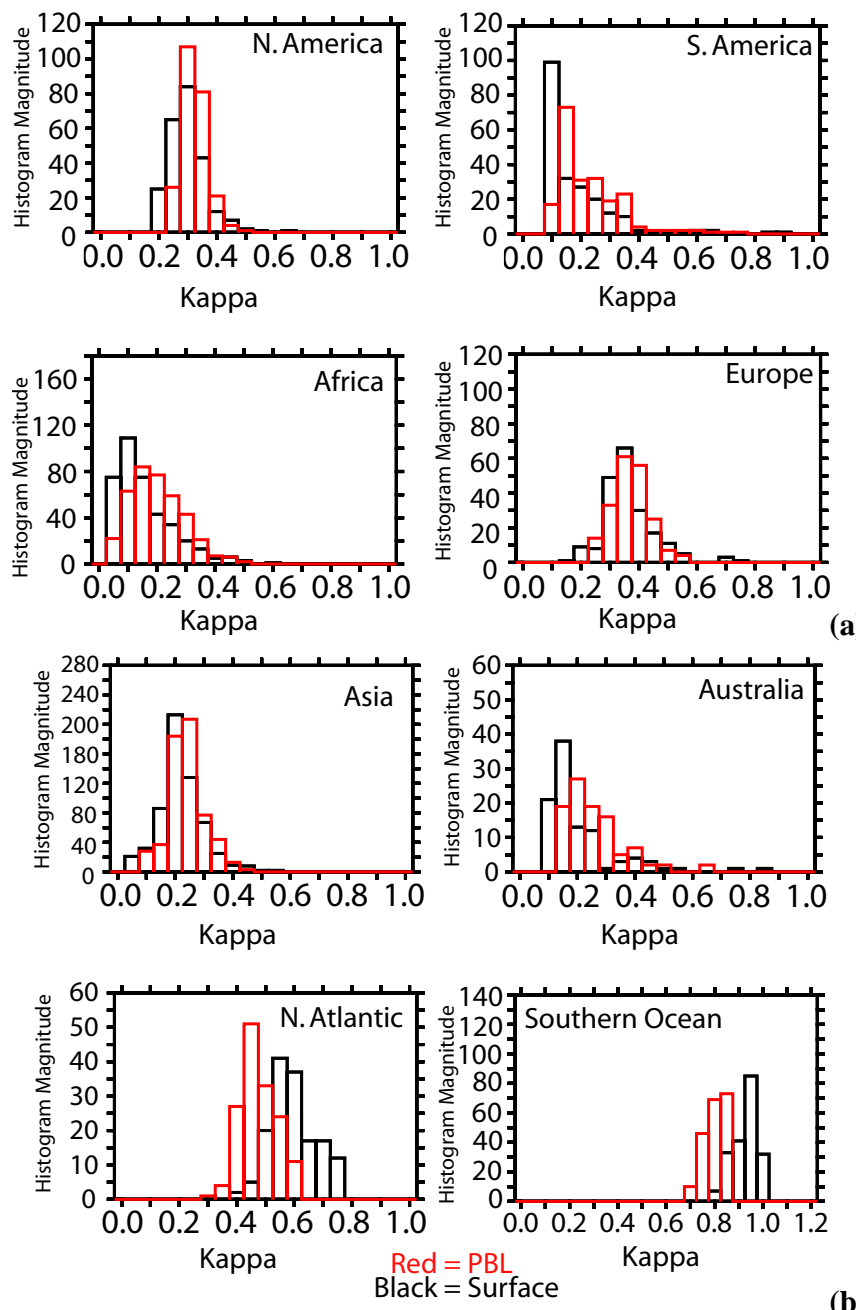

(b)

Fig. 6. Histogram of the occurrence of particular $\kappa$ values in the regions shown by the dotted boxes in Fig. 4. Histogram magnitude shows the total number of occurrences of each $\kappa$ value calculated using a field of annual mean $\kappa$ values.

spread with just a small number of grid-boxes with larger values (these are generally boxes near the coast).

In Europe and N. America $\kappa$ is larger (most values between 0.2-0.4) and the distribution is broader. This surface distribution of $\kappa$ in Asia is most frequently 0.2 , but there are also much lower values $<0.1$ from biomass burning and high values from the largely anthropogenic sulfate and nitrate aerosol.

The distribution of $\kappa$ at PBL height is similar to the surface distribution, but in continental sites there is a general shift to larger $\kappa$ values at altitude as the aerosol at altitude is generally more aged and thus the very low $\kappa$ values due to fresh dust and $\mathrm{BC}$ occur less frequently. In Europe the surface $\kappa$ is quite similar to the $\kappa$ aloft, but in N. America the frequency distribution of $\kappa$ is quite different above the
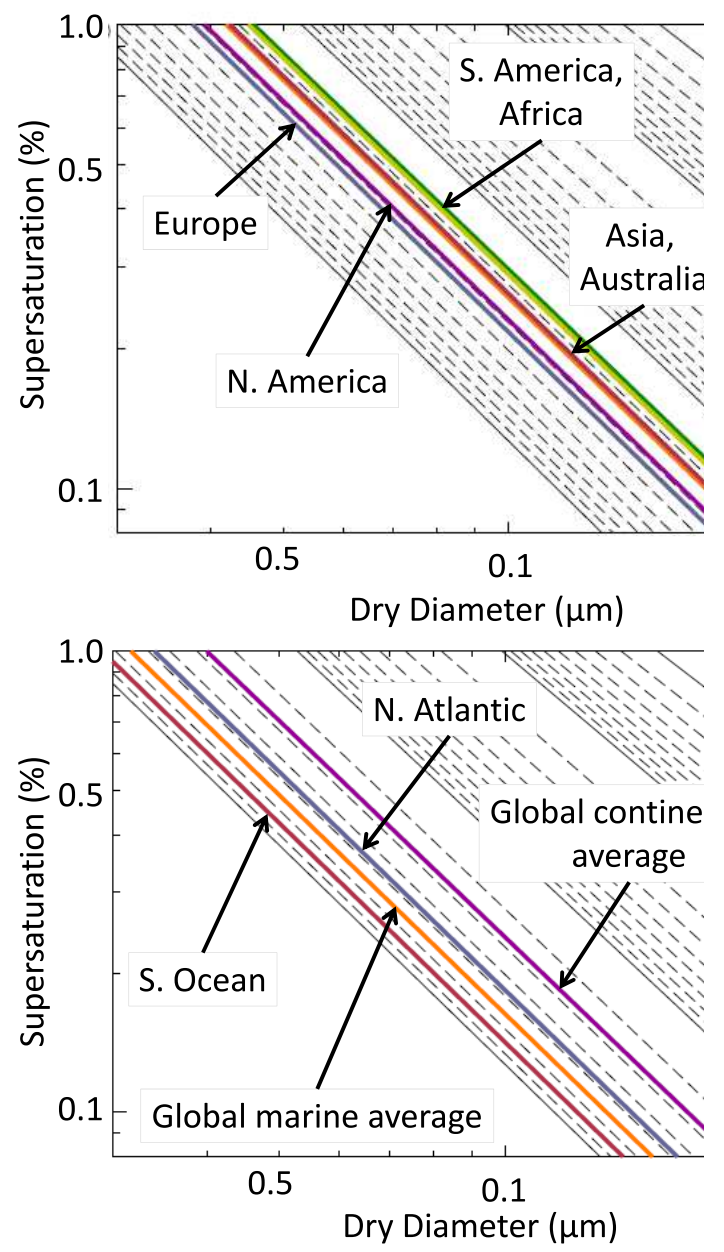

Fig. 7. The relationship between particle diameter and critical supersaturations plotted as done by Petters and Kreidenweis (2007), but with the lines corresponding to the simulated regional mean PBL $\kappa$ values highlighted.

surface layer. Thus, in this region, the dependence of $\kappa$ on altitude is important on a regional as well as a site specific scale.

\subsubsection{Marine}

Also shown in Fig. 6 is the distribution of $\kappa$ in two marine regions: the N. Atlantic and a remote section of the Southern Ocean. These regions were chosen to illustrate the potential range of marine $\kappa$ values as the Southern Ocean region is very far from continental influences and the N. Atlantic is very strongly influenced by continental outflow of pollutants and dust.

Over the Southern Ocean, $\kappa$ is very high and quite uniform. EMAC may underestimate the variability of $\kappa$ in this region because of the simple treatment of marine organic aerosol, but field measurements are needed to confirm this. 
a) Absolute difference at surface

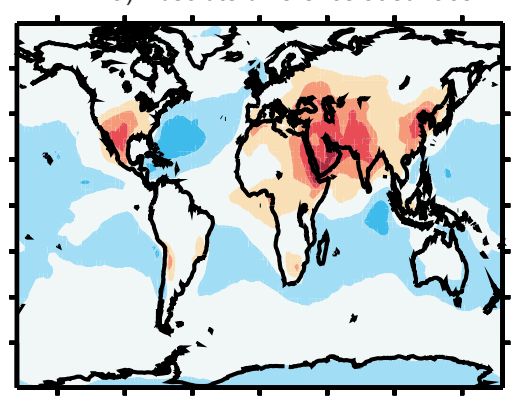

c) Percentage difference at surface

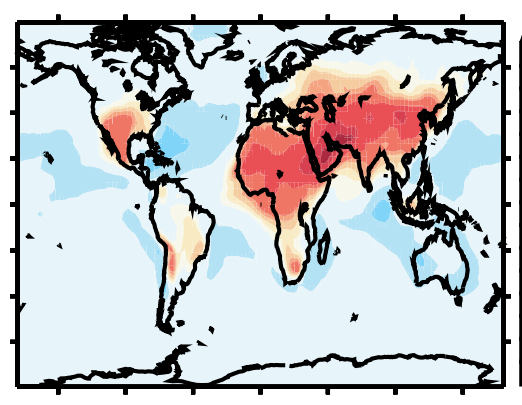

b) Absolute difference at PBL top

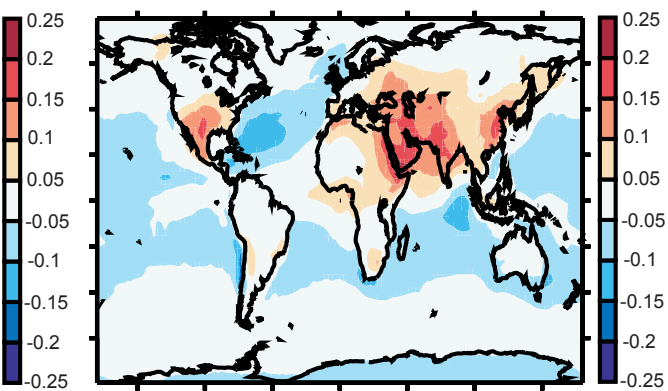

d) Percentage difference at PBL top

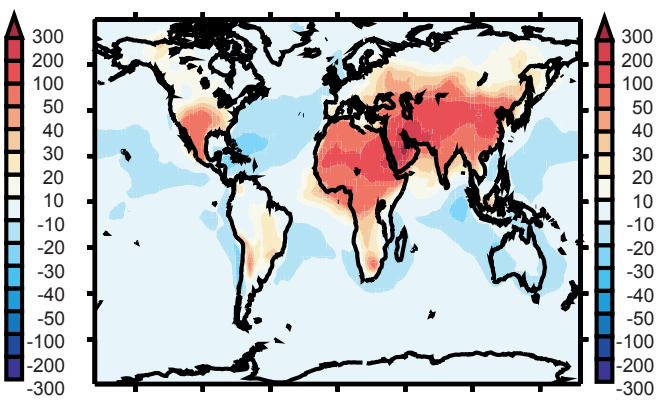

Fig. 8. Annual mean absolute difference in $\kappa$ arising from present day emissions compared to a pre-industrial scenario $\left(\kappa_{\text {present }}-\right.$

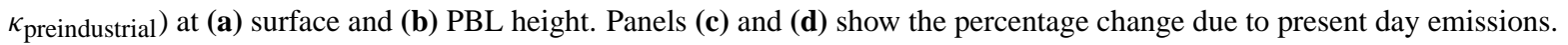

Over the N. Atlantic $\kappa$ is more variable, with no one value dominating. The aerosol in this region is a much more complex mix of species, with different $\kappa$ values. The difference in the average $\kappa$ value between these two marine regions is larger than the difference found between the various regional mean continental values (at surface: $\kappa_{\mathrm{S}}$ Ocean $=0.92$, $\kappa_{\mathrm{N}}$ Atlantic $\left.=0.59\right)$. In line with the vertical profiles in Fig. 3, the marine regions show a decrease in $\kappa$ aloft as sea spray aerosol becomes a less dominant fraction of the aerosol mass.

\subsubsection{Regional vs. temporal variability}

Table 1 shows the average annual mean $\kappa$ for each region and the standard deviation within the region. This calculation of standard deviation uses 5 hourly average $\kappa$ values for each grid box, and thus shows the deviation due to both the temporal variability and the variability within the region. In Sect. 3.4, it was shown that at point locations $\kappa$ can vary throughout the season, but the implications for this on the larger scale are unclear. To elucidate this, Table 3 shows the standard deviation of $\kappa$ for each of the regions calculated in four different ways:
1. $x, y, t_{5}$ : Allows variation in area and time (five hourly mean data, as used as default in this text).

2. $x, y$ : Allows variation in area but annual average $\kappa$ values are used.

3. $t_{5}$ : Allows for variation in time (using 5 hourly mean data) but regional average $\kappa$ values are used.

4. $t_{m}$ : Allows for variation in time (using monthly mean data) but regional average $\kappa$ values are used.

In most regions the standard deviation of $\kappa$ due to time variability is small compared to the deviation due to variability within the region implying that if a choice has to be made, it is better to focus analysis and measurements on the regional (rather than temporal) distribution of $\kappa$. N. America, however, has a more pronounced seasonal cycle than the other regions $-\kappa$ values range from 0.4 to 0.2 with a minimum in June and July. A similar cycle is found in the $\mathrm{N}$. Atlantic. In these regions the standard deviation due to variations in time $\left(t_{5}\right)$ is larger than that in space $(\mathrm{x}, \mathrm{y})$, for example in N. America St $\operatorname{Dev}_{x, y}=0.05$, St $\operatorname{Dev}_{t_{5}}=0.07$. In Europe, the standard deviations in space and time are of a similar magnitude (St $\operatorname{Dev}_{x, y}=0.08$, St $\operatorname{Dev}_{t_{5}}=0.05$ ), thus temporal variability in this region can also not be neglected. 
Table 3. Standard deviation (St Dev) of $\kappa$ values calculated considering variation in i) all dimensions $\left(\mathrm{x}, \mathrm{y}, \mathrm{t}_{5}=\right.$ area and time $\left(t_{5}=5\right.$ hourly time intervals) $)$, ii) area only $(\mathrm{x}, \mathrm{y})$, iii) time only $\left(\mathrm{t}_{5}=5\right.$ hourly time intervals $)$ and iv) time only $\left(t_{m}=\right.$ monthly mean values used). For each standard deviation value the adjacent column (to the right) shows the number of data points used in the calculation $(n)$.

\begin{tabular}{|c|c|c|c|c|c|c|c|c|c|c|}
\hline \multirow[t]{2}{*}{ Region } & \multirow{2}{*}{$\begin{array}{c}\text { Area } \\
\left(10^{13} \mathrm{~m}^{2}\right)\end{array}$} & \multirow{2}{*}{$\begin{array}{l}\text { Mean } \kappa \\
\text { Surface }\end{array}$} & \multicolumn{2}{|c|}{$\mathrm{x}, \mathrm{y}, \mathrm{t}_{5}$} & \multicolumn{2}{|c|}{$\mathrm{x}, \mathrm{y}$} & \multicolumn{2}{|c|}{$t_{5}$} & \multicolumn{2}{|c|}{$t_{m}$} \\
\hline & & & St Dev & $n$ & St Dev & $n$ & St Dev & $n$ & St Dev & $n$ \\
\hline Global (Cont.) & 14.4 & 0.27 & 0.21 & 4761936 & 0.18 & 2718 & 0.02 & 1752 & 0.02 & 12 \\
\hline Global (Marine) & 37.0 & 0.72 & 0.24 & 9702576 & 0.20 & 5538 & 0.02 & 1752 & 0.02 & 12 \\
\hline N. America & 1.61 & 0.30 & 0.15 & 420480 & 0.05 & 240 & 0.07 & 1752 & 0.07 & 12 \\
\hline S. America & 1.90 & 0.17 & 0.14 & 367920 & 0.11 & 210 & 0.02 & 1752 & 0.01 & 12 \\
\hline Africa & 3.48 & 0.15 & 0.12 & 672768 & 0.10 & 384 & 0.03 & 1752 & 0.02 & 12 \\
\hline Europe & 1.14 & 0.36 & 0.16 & 350400 & 0.08 & 200 & 0.05 & 1752 & 0.04 & 12 \\
\hline Asia & 3.64 & 0.22 & 0.15 & 1038936 & 0.08 & 593 & 0.03 & 1752 & 0.03 & 12 \\
\hline Australia & 0.87 & 0.21 & 0.16 & 173448 & 0.12 & 99 & 0.04 & 1752 & 0.01 & 12 \\
\hline N. Atlantic & 1.25 & 0.59 & 0.18 & 264552 & 0.07 & 151 & 0.11 & 1752 & 0.09 & 12 \\
\hline Southern Ocean & 1.56 & 0.92 & 0.09 & 346896 & 0.05 & 198 & 0.03 & 1752 & 0.04 & 12 \\
\hline
\end{tabular}

This analysis implies that longer term measurement campaigns are particularly required to characterise $\kappa$ in N. America, N. Atlantic and Europe, although every region shows some variation due to the annual cycle. In general, regions that experience a strong annual cycle (i.e. the midlatitudes) will clearly experience the strongest temporal variability in aerosol composition (and $\kappa$ ) and thus long term measurements would be advantageous.

The final section of Table 3 shows the St Dev due to time, calculated using monthly mean values. In the regions which have high St Dev due to time (N. America, N. Atlantic), the calculated St Dev is not sensitive to the use of monthly mean rather than 5 hourly data - implying that the deviation comes from seasonal (not short term) variations. In other regions, using monthly mean data results in a smaller St Dev (values reduced by 30 to $60 \%$ ). This happens because in regions with little seasonal cycle, short term variations are relatively more important for temporal variability. Overall in these regions, however, the deviations due to temporal variability are small compared to the St Dev due to changes in $\kappa$ across the region $(x, y)$.

\subsection{Effect of regional mean $\kappa$ on critical supersaturation required for $\mathrm{CCN}$ activation}

So far, this paper has focused on the distribution of $\kappa$ throughout the globe. The $\kappa$ value of an aerosol particle is of interest mainly because it can give information on the ability of a particle to activate during cloud formation. If variations in $\kappa$ have a sufficiently small effect on the activation ability of the aerosol they can be neglected in activation calculations, conversely if $\kappa$ varies such that the critical supersaturation $\left(S_{c}\right)$ required to activate a particle is significantly affected then the particle composition (and $\kappa$ value) must be considered in detail.
Reutter et al. (2009) examined the sensitivity of cloud droplet number (CDN) concentrations to $\kappa(0.05$ to 0.6$)$ for a typical biomass burning aerosol size distribution (assuming a single lognormal mode) using a cloud parcel model. They found the value of $\kappa$ to be important at very low values $(<0.05)$ and at larger values $(\kappa>0.3)$ if the cloud regime simulated was updraft-limited. In these cases a $50 \%$ change in the magnitude of $\kappa$ could change CDN by $\geq 10 \%$. Although this study was focused on one "typical" size distribution it indicates that changes in $\kappa$ can significantly affect $\mathrm{CDN}$, but the sensitivity depends on both $\kappa$ and the cloud regime.

In EMAC, we cannot capture the complex microphysics of a cloud parcel model, thus to place the different simulated regional mean $\kappa$ values in the context of aerosol activation, Fig. 7 shows the relationship between particle diameter and $S_{c}$ in the form shown by Petters and Kreidenweis (2007), but with the $\kappa$ lines corresponding to the mean $\kappa$ of the different regions (at PBL height) highlighted. Table 1 also shows the $S_{c}$ required to activate a particle of 60 and $120 \mathrm{~nm}$ diameter in each of the different regions.

The $S_{c}$ required for activation shows some variation between regions, for example to activate a particle of diameter $60 \mathrm{~nm}$ requires a supersaturation of $0.28 \%$ (in S. Ocean), $0.37 \%$ (N. Atlantic), $0.44 \%$ (Europe), $0.53 \%$ (Asia and Australia) and 0.6 (S. America and Africa). Similarly, to activate a $120 \mathrm{~nm}$ diameter particle requires a supersaturation of just $0.10 \%$ (in the S. Ocean), $0.13 \%$ (N. Atlantic) and $0.15 \%$ (Europe), $0.19 \%$ (Asia and Australia) and $0.21 \%$ (in S. America and Africa). These regional differences can be significant in the formation of stratiform clouds which typically takes place at low supersaturations.

Nevertheless the variation of the annual mean $\kappa$ between continental regions is small enough that the effect on $S_{c}$ (and thus $\mathrm{CCN}$ ) is relatively minor. An exception is Africa and S. America, which require a $S_{c}$ that is $\geq 20 \%$ higher than 
Table 4. Simulated aerosol burden in present day and pre-industrial conditions. Dust and sea salt emissions are identical in the present day and pre-industrial simulation. The review of previous works is taken from Tsigaridis et al. (2006), except for: A Stier et al. (2005) and ${ }^{\mathrm{B}}$ Bauer et al. (2007). $\mathrm{POM}=$ Particulate organic matter, $\mathrm{BC}=$ black carbon. All units are Tg.

\begin{tabular}{lcccc}
\hline Species & $\begin{array}{c}\text { This study } \\
\text { present day }\end{array}$ & $\begin{array}{c}\text { This study } \\
\text { pre-industrial }\end{array}$ & $\begin{array}{c}\text { Previous work } \\
\text { present }\end{array}$ & $\begin{array}{c}\text { Previous work } \\
\text { pre-industrial }\end{array}$ \\
\hline Burden $(T g)$ & & & & \\
\hline $\mathrm{SO}_{4}^{2-}$ & 1.72 & 0.66 & $0.29-2.55$ & $0.10-0.58$ \\
$\mathrm{NO}_{3}^{-}$ & 0.67 & 0.48 & $0.04-2.52^{\mathrm{B}}$ & $0.10-1.46^{\mathrm{B}}$ \\
$\mathrm{NH}_{4}^{+}$ & 0.26 & 0.03 & $0.33-0.54$ & 0.12 \\
$\mathrm{BC}$ & 0.19 & 0.04 & $0.11-0.29$ & $0.011-0.02$ \\
POM & 1.68 & 0.90 & $1.5^{\mathrm{A}}$ & $0.4^{\mathrm{A}}$ \\
\hline Sea salt & 7.19 & 7.31 & $0.97-13.21$ & \\
Dust & 14.53 & 14.84 & $7.9-35.9$ & \\
\hline
\end{tabular}

the global continental average to activate. Aerosols over the N. Atlantic and Southern Oceans require critical supersaturations that are, respectively, $+13 \%$ and $-15 \%$ different from the global mean marine $S_{c}$ value to activate. In terms of the absolute change in $S_{c}$, this effect is more important for small particles, as large particles activate at such low critical supersaturations that variations in $\kappa$ are less important.

Thus, although particle size is the dominant factor in aerosol activation, we show that there are small but systematic differences in the mean water uptake ability of the aerosol between regions, which can affect activation. The result of this is that one can reasonably expect two aerosol distributions with the same number concentration and size distribution to form different concentrations of cloud condensation nuclei (and cloud droplet number concentrations) if they originate from e.g. Asia rather than N. America or the N. Atlantic rather than the Southern Ocean. The use of globally uniform $\kappa$ values would be unable to capture this subtlety.

\subsection{Present vs. pre-industrial conditions: the influence of anthropogenic emissions}

Human activities such as energy production, biomass burning and transport are known to increase both the number and mass of aerosol particles in the atmosphere, with consequences for the radiative balance of the planet. However, in addition to changing the amount of aerosol in the atmosphere, anthropogenic emissions can also change the composition of the atmospheric aerosol, which could affect the $\mathrm{CCN}$ formation ability of the aerosol.

To investigate the change in $\kappa$ as a result of human activities, a second simulation was preformed in which emissions representative of pre-industrial conditions were used. Preindustrial emissions of $\mathrm{BC}$ and $\mathrm{OC}$ provided by AeroCom are used (Dentener et al., 2006) and pre-industrial gas emissions are from the EDGAR-HYDE inventory (Van Aardenne et al., 2001). Pre-industrial levels of $\mathrm{CO}_{2}, \mathrm{~N}_{2} \mathrm{O}$ and $\mathrm{CH}_{4}$ are nudged (using the TNUDGE submodel) to values created using a previous long-term EMAC simulation (EVAL version 2.3, $\mathrm{CO}_{2}: 284.7 \times 10^{-6}, \mathrm{CH}_{4}: 791.60 \times 10^{-9}$ and $\mathrm{N}_{2} \mathrm{O}$ : $275.68 \times 10^{-9} \mathrm{~mol} \mathrm{~mol}^{-1}$ ). For the pre-industrial simulation we use the same nudged meteorology as the present day run and no feedbacks of the aerosol or chemistry on radiation (and thus meteorology) are considered. Emission of dust and sea salt aerosol are also held constant. Nevertheless, the burden of these species may change as the degree and extent of mixing between hydrophobic and hydrophilic compounds can influence the aerosol scavenging efficiency by clouds and precipitation. A summary of the aerosol burdens for both simulations is given in Table 4 .

Figure 8 shows the change in $\kappa$ at both the surface and PBL height between the two simulations. Comparing the present with the pre-industrial scenario, many marine $\kappa$ values are reduced by 0.05 (or 10\%). Over the continents, however, present day $\kappa$ values are larger, particularly in Africa, N. America, India and Saudi Arabia.

The change in $\kappa$ (Table 5) can be understood by considering the change in the aerosol composition of the different regions. In the pre-industrial scenario, marine aerosol is almost entirely sea spray aerosol, which is very hydrophilic. Anthropogenic pollution is only moderately hydrophilic, thus an increase in anthropogenic aerosol reduces the fraction of sea spray in the aerosol, and thus reduces $\kappa$. This is most important where outflow of anthropogenic aerosol to the oceans is large and low wind speeds lead to small sea spray loadings.

In continental regions, however, the pre-industrial aerosol is made up of dust and organic matter, with some sulfate from natural sources, leading to an aerosol distribution that is only moderately hydrophilic (global mean continental $\kappa$ Preindustrial $=0.23 \pm 0.24$, reduced from $\kappa_{\text {Present }}=0.27 \pm 0.21$ ). An increase in anthropogenic pollution adds large amounts of sulfate and nitrate aerosol, leading to an increase in $\kappa$ in continental regions. 
Table 5. Simulated global and regional annual mean $\kappa$ values (and standard deviation) at the surface and at the simulated PBL height under pre-industrial conditions. Standard deviation is calculated for the year from 5-hourly average data. $S_{c}$ is the critical supersaturation (\%), calculated using the regional mean $\kappa$ at PBL height. Area column gives total land area for land sites, and marine area for marine sites.

\begin{tabular}{lccccccc}
\hline Region & $\begin{array}{c}\text { Area } \\
\left(10^{13} \mathrm{~m}^{2}\right)\end{array}$ & $\begin{array}{c}\text { Mean } \kappa \\
\text { Surface }\end{array}$ & $\begin{array}{c}\text { St Dev } \\
\text { Surface }\end{array}$ & $\begin{array}{c}\text { Mean } \kappa \\
\text { PBL height }\end{array}$ & $\begin{array}{c}\text { St Dev } \\
\text { PBL height }\end{array}$ & $\begin{array}{c}S_{c}(\%) \\
D_{p}=60(\mathrm{~nm})\end{array}$ & $\begin{array}{c}S_{c}(\%) \\
D_{p}=120(\mathrm{~nm})\end{array}$ \\
\hline Global (Continental) & 1.44 & 0.23 & 0.24 & 0.24 & 0.23 & 0.51 & 0.18 \\
Global (Marine) & 3.70 & 0.76 & 0.25 & 0.63 & 0.27 & 0.33 & 0.11 \\
\hline N. America & 1.61 & 0.26 & 0.19 & 0.25 & 0.17 & 0.50 & 0.18 \\
S. America & 1.90 & 0.17 & 0.15 & 0.18 & 0.15 & 0.59 & 0.21 \\
Africa & 3.48 & 0.09 & 0.11 & 0.11 & 0.11 & 0.75 & 0.27 \\
Europe & 1.14 & 0.30 & 0.22 & 0.27 & 0.20 & 0.48 & 0.17 \\
Asia & 3.64 & 0.15 & 0.15 & 0.15 & 0.14 & 0.65 & 0.23 \\
Australia & 0.87 & 0.23 & 0.19 & 0.26 & 0.17 & 0.49 & 0.17 \\
\hline N. Atlantic & 1.25 & 0.71 & 0.21 & 0.57 & 0.23 & 0.33 & 0.12 \\
Southern Ocean & 1.56 & 0.95 & 0.07 & 0.85 & 0.16 & 0.27 & 0.10 \\
\hline
\end{tabular}

The critical supersaturation (\%) required to activate an aerosol of a particular size is also altered by present day emissions, for example the change in $S_{c}$ required for a $60 \mathrm{~nm}$ particle is $\left(S_{\mathrm{c} \text { Present }}-S_{\mathrm{c} \text { Pre-industrial }}\right):+0.04$ (N. Atlantic), -0.04 (Europe), -0.14 (Africa), -0.11 (Asia). Overall Asia and Africa are the most sensitive regions a reduction in $S_{c}$ of $\geq 17 \%$ due to present day emissions. Thus in polluted continental regions, anthropogenic emissions not only increase the amount of aerosol present, but also increases the ease with which a particle of a particular size can activate.

The dominant effect of modern day emissions on $\mathrm{CCN}$ (and thus cloud droplet number) concentrations is the well documented increase in aerosol number and mass loading that has occurred since the industrial revolution. The change in $\kappa$, however, allows us to identify an additional, but more subtle effect. We find that the critical supersaturation required to activate an aerosol of a particular size was systematically different under pre-industrial conditions. However, the implications for this on CCN cannot be assessed without also considering the change in the aerosol number and size distribution that has occurred.

Thus, although particle size and number are the dominant factors in aerosol activation, we find that anthropogenic emissions have caused small but systematic differences in the water uptake ability of the aerosol, which may have implications for the formation of clouds and precipitation. These changes are particularly important for mineral dust aerosols which are large enough to activate at low supersaturations, but are hydrophobic on emission and thus are sensitive to small changes in $\kappa$.

\section{Conclusions}

In this paper we show global fields of the $\kappa$ hygroscopicity parameter developed by Petters and Kreidenweis (2007). Although $\kappa$ has already been used in a range of field and modelling studies, to our knowledge this is the first time the global distribution of $\kappa$ has been presented. The global fields give us a number of insights into the water uptake ability of atmospheric aerosols. We find that:

- The simulated global mean $\kappa$ at the surface is $0.27 \pm 0.21$ over land and $0.72 \pm 0.24$ for marine regions, this agrees well with the estimates of Andreae and Rosenfeld (2008), although our study predicts a standard deviation of continental $\kappa$ that is double the previous estimate

- The distribution of $\kappa$ is found to be fairly uniform within a region (as was suggested by field measurements), with regions of hundreds of kilometers showing little change in $\kappa$.

- There are, however, differences between regions which may be important. For example N. America and Europe, which have a higher influence of sulfate and nitrate aerosol have a mean $\kappa$ of 0.3 and 0.36 respectively, but African and S. American aerosol are less hygroscopic $(\kappa=0.15,0.17)$. This implies that if an estimated value of $\kappa$ must be used, a continental-scale $\kappa$ is more appropriate than a global one.

- In many marine regions, $\kappa$ is reduced by the outflow of natural and anthropogenic aerosol from the continents. For example, $\kappa$ over the S. Ocean is 0.92 but it is just 0.59 over the N. Atlantic. Thus although continental outflow generally increases the number and mass of aerosol present, is also reduces the ability of a particle of a particular size to activate. 
- The variation of $\kappa$ in the vertical can be important, particularly in marine regions which consistently show a strong decrease in $\kappa$ with altitude. In continental regions the vertical gradient is not so strong and varies between regions.

- The standard deviation of $\kappa$ within a region mostly arises from variations in the horizontal distribution, and to a much lesser degree due to temporal variability. The exception to this is the N. Atlantic and N. America, which show larger temporal variability. This variability is well captured by monthly mean values, implying that the temporal variation arises from seasonal (and not shorter term) variations.

- The global distribution of $\kappa$ under pre-industrial conditions is different from present day $\kappa$. Although this effect of the change in aerosol chemistry on $\mathrm{CCN}$ is small compared to the effect of the increase in aerosol loading with the anthropogenic emissions, it is interesting to note that under pre-industrial conditions the same aerosol number and size distribution would give a different CCN loading. In summary, we find that under pre-industrial conditions, some marine regions (particularly the Gulf of Mexico) had higher $\kappa$ values and thus were more able to activate at a particular supersaturation, while the converse is true for continental regions where anthropogenic pollution tends to increase $\kappa$, and thus increase the ease with which a particle of a particular size activates.

Acknowledgements. The authors would like to thank Hang $\mathrm{Su}$ at the MPI Chemistry for the useful discussion and collaboration. We also wish to thank colleagues at the MPI including Patrick Jöckel, Benedikt Steil, Astrid Kerkweg and Andreas Baumgärtner for help with the EMAC model. We acknowledge support by the European Research Council through the $\mathrm{C} 8$ project.

Further we thank Julian Wilson and Elisabetta Vignatti (JRC, Ispra) for the M7 model, Philip Stier for its implementation in ECHAM5, Frank Dentener (JRC) and the former partners of the EU-project PHOENICS (http://phoenics.chemistry.uoc.gr/) for many fruitful discussions, and Swen Metzger for the initial development of GMXe.

The service charges for this open access publication have been covered by the Max Planck Society.

Edited by: J. Quaas

\section{References}

Allan, J. D., Baumgardner, D., Raga, G. B., Mayol-Bracero, O. L., Morales-Garca, F., Garca-Garca, F., Montero-Martnez, G., Borrmann, S., Schneider, J., Mertes, S., Walter, S., Gysel, M., Dusek, U., Frank, G. P., and Krmer, M.: Clouds and aerosols in Puerto Rico - a new evaluation, Atmos. Chem. Phys., 8, 1293-1309, 2008, http://www.atmos-chem-phys.net/8/1293/2008/.

Andreae, M. O. and Rosenfeld, D.: Aerosol-cloudprecipitation interactions. Part 1. The naturea and sources of cloud-active aerosols, Earth. Sci. Rev.,89, doi:10.1016/j.earscirev.2008.03.001, 2008.

Bauer, S. E., Mishchenko, M. I., Lacis, A. A., Zhang, S., Perlwitz, J., and Metzger, S. M.: Do sulfate and nitrate coatings on mineral dust have important effects on radiative properties and climate modeling?, J. Geophys. Res.-Atmos., 112, D06307, doi:10.1029/ 2005JD006977, 2007.

Bougiatioti, A., Fountoukis, C., Kalivitis, N., Pandis, S. N., Nenes, A., and Mihalopoulos, N.: Cloud condensation nuclei measurements in the marine boundary layer of the Eastern Mediterranean: $\mathrm{CCN}$ closure and droplet growth kinetics, Atmos. Chem. Phys., 9, 7053-7066, 2009,

http://www.atmos-chem-phys.net/9/7053/2009/.

Broekhuizen, K., Chang, R.-W., Leaitch, W. R., Li, S.-M., and Abbatt, J. P. D.: Closure between measured and modeled cloud condensation nuclei (CCN) using size-resolved aerosol compositions in downtown Toronto, Atmos. Chem. Phys., 6, 2513-2524, 2006, http://www.atmos-chem-phys.net/6/2513/2006/.

Chang, R. Y.-W., Slowik, J. G., Shantz, N. C., Vlasenko, A., Liggio, J., Sjostedt, S. J., Leaitch, W. R., and Abbatt, J. P. D.: The hygroscopicity parameter $(\kappa)$ of ambient organic aerosol at a field site subject to biogenic and anthropogenic influences: relationship to degree of aerosol oxidation, Atmos. Chem. Phys., 10, 50475064, doi:10.5194/acp-10-5047-2010, 2010.

Cubison, M. J., Ervens, B., Feingold, G., Docherty, K. S., Ulbrich, I. M., Shields, L., Prather, K., Hering, S., and Jimenez, J. L.: The influence of chemical composition and mixing state of Los Angeles urban aerosol on CCN number and cloud properties, Atmos. Chem. Phys., 8, 5649-5667, 2008, http://www.atmos-chem-phys.net/8/5649/2008/.

Dentener, F., Kinne, S., Bond, T., Boucher, O., Cofala, J., Generoso, S., Ginoux, P., Gong, S., Hoelzemann, J. J., Ito, A., Marelli, L., Penner, J. E., Putaud, J.-P., Textor, C., Schulz, M., van der Werf, G. R., and Wilson, J.: Emissions of primary aerosol and precursor gases in the years 2000 and 1750, prescribed data-sets for AeroCom, Atmos. Chem. Phys., 6, 4321-4344, 2006, http://www.atmos-chem-phys.net/6/4321/2006/.

Dusek, U., Frank, G. P., Hildebrandt, L., Curtius, J., Schneider, J., Walter, S., Chand, D., Drewnick, F., Hings, S., Jung, D., Borrmann, S., and Andreae, M. O.: Size Matters More Than Chemistry for Cloud-Nucleating Ability of Aerosol Particles, Science, 312, 1375-1378, doi:10.1126/science.1125261, 2006.

Dusek, U., Frank, G. P., Curtius, J., Drewnick, F., Schneider, J., Küurten, A., Rose, D., Andreae, M. O., Borrmann, S., , and Pöschl, U.: Enhanced organic mass fraction and decreased hygroscopicity of cloud condensation nuclei (CCN) during new particle formation events, Geophys. Res. Lett., 37, L03804, doi:10.1029/2009GL040 930, 2010.

Ganzeveld, L. and Lelieveld, J.: Dry deposition parametrization in a chemistry general circulation model and its influence on the dis- 
tribution of reactive trace gases, J. Geophys. Res.-Atmos., 100, 20999-21012, doi:http://dx.doi.org/10.1029/95JD02266, 1995.

Guibert, S., Snider, J. R., and Brenguier, J.-L.: Aerosol activation in marine stratocumulus clouds: 1 . Measurement validation for a closure study, J. Geophys. Res. - Atmos., 108, 8628, doi:10.1029/2002JD002678, 2003.

Gunthe, S. S., King, S. M., Rose, D., Chen, Q., Roldin, P., Farmer, D. K., Jimenez, J. L., Artaxo, P., Andreae, M. O., Martin, S. T., and Pöschl, U.: Cloud condensation nuclei in pristine tropical rainforest air of Amazonia: size-resolved measurements and modeling of atmospheric aerosol composition and CCN activity, Atmos. Chem. Phys., 9, 7551-7575, 2009, http://www.atmos-chem-phys.net/9/7551/2009/.

Holtslag, A. A. M. and Boville, B. A.: Local Versus Nonlocal Boundary-Layer Diffusion in a Global Climate Model., J. Clim., 6, 1825-1842, 1993.

Holtslag, A. A. M., de Bruijn, E. I. F., and Pan, H.-L.: A high resolution air mass transformation model for short-range weather forecasting, Mon. Weather Rev., 118, 1561-1575, 1990.

Hudson, J. G.: Variability of the relationship between particle size and cloud-nucleating ability, Geophys. Res. Lett., 34, L08801, doi:10.1029/2006GL028850, 2007.

Jöckel, P., Sander, R., Kerkweg, A., Tost, H., J., and Lelieveld, J.: Technical Note: The Modular Earth Submodel System (MESSy) - a new approach towards Earth System Modeling, Atmos. Chem. Phys., 5, 433-444, 2005,

http://www.atmos-chem-phys.net/5/433/2005/.

Jöckel, P., Tost, H., Pozzer, A., Brühl, C., Buchholz, J., Ganzeveld, L., Hoor, P., Kerkweg, A., Lawrence, M., Sander, R., Steil, B., Stiller, G., Tanarhte, M., Taraborrelli, D., van Aardenne, J., and Lelieveld, J.: The atmospheric chemistry general circulation model ECHAM5/MESSy1: consistent simulation of ozone from the surface to the mesosphere, Atmos. Chem. Phys., 6, 50675104, 2006, http://www.atmos-chem-phys.net/6/5067/2006/.

Kandler, K. and Shütz: Climatology of the Average Water-soluble Volume Fraction of Atmospheric Aerosol, Atmos. Res, 07, 7792, 2007.

Kerkweg, A., Buchholz, J., Ganzeveld, L., Pozzer, A., Tost, H., and Jöckel, P.: Technical Note: An implementation of the dry removal processes DRY DEPosition and SEDImentation in the Modular Earth Submodel System (MESSy), Atmos. Chem. Phys., 6, 4617-4632, 2006a.

Kerkweg, A., Sander, R., Tost, H., and Jöckel, P.: Technical note: Implementation of prescribed (OFFLEM), calculated (ONLEM), and pseudo-emissions (TNUDGE) of chemical species in the Modular Earth Submodel System (MESSy), Atmos. Chem. Phys., 6, 3603-3609, 2006b.

Kerkweg, A., Jöckel, P., Tost, H., Sander, R., Schulz, M., Stier, P., Vignati, E., Wilson, J., and Lelieveld, J.: Consistent simulation of bromine chemistry from the marine boundary layer to the stratosphere. Part 1: Model description, sea salt aerosols and $\mathrm{pH}$, Atmos. Chem. Phys., 8, 5899-5917, 2008,

http://www.atmos-chem-phys.net/8/5899/2008/.

Kim, D., Wang, C., Ekman, A. M. L., Barth, M. C., and J., R. P.: Distribution and direct radiative forcing of carbonaceous and sulfate aerosols in an interactive sizeresolving aerosolclimate model, J. Geophys. Res.-Atmos., 113, doi:10.1029/2007JD009756, 2008.

King, S. M., Rosenoern, T., Shilling, J. E., Chen, Q., Wang, Z.,
Biskos, G., McKinney, K. A., Pöschl, U., and Martin, S. T.: Cloud droplet activation of mixed organic-sulfate particles produced by the photooxidation of isoprene, Atmos. Chem. Phys., 10, 3953-3964, 2010,

http://www.atmos-chem-phys.net/10/3953/2010/.

Mikhailov, E., Vlasenko, S., Martin, S. T. Koop, T., and Pöschl, U.: Amorphous and crystalline aerosol particles interacting with water vapor: conceptual framework and experimental evidence for restructuring, phase transitions and kinetic limitations, Atmos. Chem. Phys., 9, 9491-9522, 2009,

http://www.atmos-chem-phys.net/9/9491/2009/.

Morgan, W. T., Allan, J. D., Bower, K. N., Capes, G., Crosier, J., Williams, P. I., and Coe, H.: Vertical distribution of sub-micron aerosol chemical composition from North-Western Europe and the North-East Atlantic, Atmos. Chem. Phys., 5389-5401, 2009.

Niedermeier, D., Wex, H., Voigtländer, J., Stratmann, F., Brüggemann, E., Kiselev, A., Henk, H., and Heintzenberg, J.: LACIS-measurements and parameterization of sea-salt particle hygroscopic growth and activation, Atmos. Chem. Phys., 8, 579590, 2008, http://www.atmos-chem-phys.net/8/579/2008/.

Petters, M. D. and Kreidenweis, S. M.: A single parameter representation of hygroscopic growth and cloud condensation nucleus activity, Atmos. Chem. Phys., 7, 1961-1971, 2007, http://www.atmos-chem-phys.net/7/1961/2007/.

Pöschl, U., Rose, D., and Andreae, M. O.: Climatologies of Cloudrelated Aerosols - Part 2: Particle Hygroscopicity and Cloud Condensation Nuclei Activity, in: Clouds in the Perturbed Climate System, edited by: Heintzenberg, J. and Charlson, R. J., MIT Press, Cambridge, ISBN 978-0-262-012874, 58-72, 2009.

Pringle, K. J., Tost, H., Metzger, S., Steil, B., Giannadaki, D., Nenes, A., Fountoukis, C., Stier, P., Vignati, E., and Lelieveld, J.: Description and evaluation of GMXe: a new aerosol submodel for global simulations (v1), Geosci. Model Dev. Discuss., 3, 569-626, doi:10.5194/gmdd-3-569-2010, 2010.

Reutter, P., Su, H., Trentmann, J., Simmel, M., Rose, D., Gunthe, S. S., Wernli, H., Andreae, M. O., and Pöschl, U.: Aerosoland updraft-limited regimes of cloud droplet formation: influence of particle number, size and hygroscopicity on the activation of cloud condensation nuclei (CCN), Atmos. Chem. Phys., 9, 7067-7080, 2009, http://www.atmos-chem-phys.net/9/7067/2009/.

Roeckner, E., Brokopf, R., Esch, M., Giorgetta, M., Hagemann, S., Kornblueh, L., Manzini, E., Schlese, U., and Schulzweida, U.: Sensitivity of simulated climate to horizontal and vertical resolution in the ECHAM5 atmosphere model, J. Climate, 19, 3371-3791, doi:10.1175/JCLI3824.1, 2006.

Rose, D., Gunthe, S. S., Mikhailov, E., Frank, G. P., Dusek, U., Andreae, M. O., and U, P.: Calibration and measurement uncertainties of a continuous-flow cloud condensation nuclei counter (DMT-CCNC): CCN activation of ammonium sulfate and sodium chloride aerosol particles in theory and experiment, Atmos. Chem. Phys., 8, 1153-1179, 2008, http://www.atmos-chem-phys.net/8/1153/2008/.

Rose, D., Nowak, A., Achtert, P., Wiedensohler, A., Hu, M., Shao, M., Zhang, Y., Andreae, M. O., and U., P.: Cloud condensation nuclei in polluted air and biomass burning smoke near the megacity Guangzhou, China Part 1: Size-resolved measurements and implications for the modeling of aerosol particle hygroscopicity and CCN activity, Atmos. Chem. Phys., 10, 3365-3383, 2010, 
http://www.atmos-chem-phys.net/10/3365/2010/.

Ruehl, C. R., Chuang, P. Y., and Nenes, A.: Distinct CCN activation kinetics above the marine boundary layer along the California coast, Geophys. Res. Lett., 36, L15814, doi:10.1029/2009GL038 839, 2009.

Sander, R., Kerkweg, A., Jöckel, P., and Lelieveld, J.: Technical note: The new comprehensive atmospheric chemistry module MECCA, Atmos. Chem. Phys., 5, 445-450, 2005, http://www.atmos-chem-phys.net/5/445/2005/.

Shinozuka, Y., Clarke, A. D., DeCarlo, P. F., Jimenez, J. L., Dunlea, E. J., Roberts, G. C., Tomlinson, J. M., Collins, D. R., Howell, S. G., Kapustin, V. N., McNaughton, C. S., and Zhou, J.: Aerosol optical properties relevant to regional remote sensing of $\mathrm{CCN}$ activity and links to their organic mass fraction: airborne observations over Central Mexico and the US West Coast during MILAGRO/INTEX-B, Atmos. Chem. Phys., 9, 6727-6742, 2010, http://www.atmos-chem-phys.net/9/6727/2010/.

Snider, J. R. and Petters, M. D.: Optical particle counter measurement of marine aerosol hygroscopic growth, Atmos. Chem. Phys., 8, 1949-1962, 2008, http://www.atmos-chem-phys.net/8/1949/2008/.

Spracklen, D. V., Carslaw, K. S., Kulmala, M., Kerminen, V. M., Sihto, S. L., Riipinen, I., Merikanto, J., Mann, G. W., Chipperfield, M. P., Wiedensohler, A., Birmili, W., and Lihavainen, H.: Contribution of particle formation to global cloud condensation nuclei concentrations, Geophys. Res. Lett., 35, L06808, doi:10.1029/2007GL033038, 2008.

Stier, P., Feichter, J., Kinne, S., Kloster, S., Vignati, E., Wilson, J., Ganzeveld, L., Tegen, I., Werner, M., Balkanski, Y., Schulz, M., Boucher, O., Minikin, A., and Petzold, A.: The aerosolclimate model ECHAM5-HAM, Atmos. Chem. Phys., 5, 11251156, doi:10.5194/acp-5-1125-2005, 2005.

Tost, H., Jöckel, P., and Lelieveld, J.: Influence of different convection parameterisations in a GCM, Atmos. Chem. Phys., 6, 54755493, 2006, http://www.atmos-chem-phys.net/6/5475/2006/.

Tost, H., Jöckel, P., Kerkweg, A., Pozzer, A., Sander, R., and Lelieveld, J.: Global cloud and precipitation chemistry and wet deposition: tropospheric model simulations with ECHAM5/MESSy1, Atmos. Chem. Phys., 7, 2733-2757, 2007a.

Tost, H., Jöckel, P., and Lelieveld, J.: Lightning and convection parameterisations - uncertainties in global modelling, Atmos. Chem. Phys., 7, 4553-4568, 2007b.
Tsigaridis, K., Krol, M., Dentener, F. J., Balkanski, Y., Lathière, J., Metzger, S., Hauglustaine, D. A., and Kanakidou, M.: Change in global aerosol composition since preindustrial times, Atmos. Chem. Phys., 6, 5143-5162, 2006, http://www.atmos-chem-phys.net/6/5143/2006/.

Van Aardenne, J., Dentener, F., Olivier, J., Klein Goldewijk, C., and Lelieveld, J.: A High Resolution Dataset of Historical Anthropogenic Trace Gas Emissions for the Period 1890-1990, Global Biogeochem. Cy., 15, 909-928, 2001.

Vestin, A., Rissler, J., Swietlicki, E., Frank, G. P., and Andreae, M. O.: Cloud-nucleating properties of the Amazonian biomass burning aerosol: Cloud condensation nuclei measurements and modeling, J. Geophys. Res.-Atmos., 112, D14201, doi:10.1029/2006JD008104, 2007.

Vignati, E., Wilson, J., and Stier, P.: M7: An efficient size-resolved aerosol microphysics module for large-scale aerosol transport models, Journal of Geophysical Research, 109, D22202, doi: http://dx.doi.org/10.1029/2003JD004485, 2004.

Wang, J., Lee, Y.-N., Daum, P. H., Jayne, J., and Alexander, M. L.: Effects of aerosol organics on cloud condensation nucleus $(\mathrm{CCN})$ concentration and first indirect aerosol effect, Atmos. Chem. Phys., 8, 6325-6339, 2008, http://www.atmos-chem-phys.net/8/6325/2008/.

Wex, H., Petters, M. D., Carrico, C. M., Hallbauer, E., Massling, A., McMeeking, G. R., Poulain, L., Wu, Z., Kreidenweis, S. M., and Stratmann, F.: Towards closing the gap between hygroscopic growth and activation for secondary organic aerosol: Part 1 Evidence from measurements, Atmos. Chem. Phys., 9, 39873997, 2009, http://www.atmos-chem-phys.net/9/3987/2009/.

Wex, H., McFiggans, G., Henning, S., and Stratmann, F.: Influence of the external mixing state of atmospheric aerosol on derived CCN number concentrations, Geophys. Res. Lett., 37, L10805, doi:10.1029/2010GL043 337, 2010.

Zhou, J., Swietlicki, E., Hansson, H. C., and Artaxo, P.: Submicrometer aerosol particle size distribution and hygroscopic growth measured in the Amazon rain forest during the wet season, J. Geophys. Res. Atmos., 107, 8055, doi:10.1029/2000JD000203, 2002. 